\title{
Bioethanol Production from Horticultural Waste Using Crude Fungal Enzyme Mixtures Produced by Solid State Fermentation
}

\author{
Fengxue Xin · Haojun Zhang • Weichong Wong
}

Published online: 7 May 2013

(C) The Author(s). This article is published with open access at Springerlink.com

\begin{abstract}
It was desired to study efficient and simplified methods to convert organosolv-pretreated horticultural waste (HW) to ethanol fuel using cellulase produced under solid-state fermentation (SSF). The unprocessed cellulase crude $(72.2 \%)$ showed better reducing sugar yield using filter paper than the commercial enzyme blend (68.7\%). Enzymatic hydrolysis of organosolv-pretreated HW using the crude cellulase with $20 \%$ solid content, enzyme loading of $15 \mathrm{FPU} / \mathrm{g} \mathrm{HW}$ at $50{ }^{\circ} \mathrm{C}$, and $\mathrm{pH} 5.5$ resulted in a $\mathrm{HW}$ hydrolysate containing $25.06 \mathrm{~g} / \mathrm{L}$ glucose after $72 \mathrm{~h}$. Fermentation of the hydrolysate medium produced $12.39 \mathrm{~g} / \mathrm{L}$ ethanol with $0.49 \mathrm{~g} / \mathrm{g}$ yield from glucose and $0.062 \mathrm{~g} / \mathrm{g}$ yield from HW at $8 \mathrm{~h}$ using Saccharomyces cerevisiae. This study proved that crude cellulase complex produced under SSF and organosolv pretreatment can efficiently convert woody biomass to ethanol without any commercial cellulase usage.
\end{abstract}

Keywords Cellulase.Organosolv pretreatment.Horticultural waste.Solid state fermentation.Ethanol

\section{Introduction}

Overall energy consumption is increasing with the growing world population and rapid industrial growth; as a result, resources of non-renewable energy are depleting very fast,

F. Xin $(\bowtie) \cdot$ H. Zhang $\bullet$ W. Wong

Department of Civil and Environmental Engineering, National University of Singapore, T-Lab 07-03N, 5A Engineering Drive 1,

Singapore, Singapore, 117576

e-mail: ceexf@nus.edu.sg resulting in increase of price. Biofuel is a renewable and environmentally favorable alternative to fossil fuels, which is presently produced from starch- and sugar-based crops [1]. Lignocellulosic biomass has been considered as the ideal feedstock for biofuel production as it does not compete with food resources and can potentially reduce carbon dioxide emission by up to 75-100 \% compared to fossil fuels $[1,2]$. Bioconversion of lignocellulosic biomass to biofuel consists of three major steps: (1) pretreatment to recover the lignin and hemicellulose in a useful form and increase accessibility of the cellulose to hydrolytic enzymes, (2) enzymatic hydrolysis of cellulose, and (3) fermentation of the resulting monosaccharides to biofuel. Producing inexpensive sugars for biofuel production depends upon sourcing inexpensive feedstocks and using efficient pretreatment and enzymatic hydrolysis steps [3, 4].

Singapore is a small island city state with a dense population living in a limited land area. As an urbanized city, it needs to address challenges to processing metropolitan wastes in a sustainable manner. In the past few years, approximately 246,200 tonnes of wood waste and 224,600 tonnes of horticultural waste (HW) were generated annually in Singapore, while the recycling rate was $71 \%$ for wood waste and only $42.4 \%$ for horticultural waste (http://www.zerowaste.sg.com). Woody biomass is also sustainably available in large quantities across the world. Wood waste includes pallets, crates, boxes, furniture, and wood planks used in construction. HW refers to tree trunks and branches, plant parts, and trimmings generated during the maintenance and pruning of trees and plants [2,4]. The recycled $\mathrm{HW}$ is usually processed into wood chips for composting or burnt to produce heat and power. $\mathrm{HW}$ is composed on average of $34.5 \%$ cellulose, $28.6 \%$ hemicel- 
lulose, and $36.0 \%$ lignin [5]; the high carbohydrate content makes $\mathrm{HW}$ an attractive feedstock for fuel ethanol production.

Successful conversion of such waste biomass to fuel ethanol will not only help solve pollution problems caused by incineration and land filling in Singapore but also could create a new revenue stream [4]. When compared to nonwoody (e.g., wheat straw) biomass, woody biomass (e.g., HW) is physically larger, structurally stronger, and denser than agricultural biomass $[4,6]$. Two issues that need to be addressed with regard to using $\mathrm{HW}$ for ethanol production are developing an efficient pretreatment and managing the cost of cellulases. Chemically, woody biomass has higher lignin content than agricultural biomass. As a result, woody biomass is more recalcitrant to microbial and enzymatic digestion than non-woody biomass [4]. Purchasing cellulases is a significant processing cost for production of ethanol. Commercial cellulase production is energy intensive and a significant contributor to the overall environmental impact of the cellulose to ethanol conversion process [7]. To successfully convert HW to bioethanol, the two key issues had been addressed in our previous work (Fig. 1):

1. Crude cellulase complex production from HW by solid state fermentation: The production of cellulase has been widely studied in submerged culture processes, but SSF has begun to become more popular mainly due to its advantages over submerged fermentation, including low capital investment, solid waste management, reduced energy requirements, improved product recovery, etc. [7-11]. In our previous study, an attempt had been made to develop a suitable and cost-effective process for the production of cellulolytic and hemicellulolytic enzymes using $\mathrm{HW}$ as the solid substrate and employing Trichoderma reesei, a fungus that has been extensively studied for cellulase production [12]. Using this crude unprocessed cellulase avoids several processing steps associated with commercial cellulase preparations (purification, concentration, addition of buffers, stabilizers, and preservatives, freeze-drying, and packaging) and consequently reduces enzyme cost.

2. Organosolv pretreatment of HW: Many methods have been developed to reduce biomass recalcitrance, such as dilute acid pretreatment, steam explosion, $\mathrm{CO}_{2}$ explosion, $\mathrm{pH}$-controlled water pretreatment, ammonia fiber expansion, ammonia recycle percolation, organosolv and lime pretreatment, of which several are being pursued [13-17]. Among these, organosolv pretreatment is more effective in removing the recalcitrance of lignocellulose, in particular, woody biomass, for enzymatic cellulose saccharification [15-17]. A modified organosolv pretreatment method conducted under non-corrosive and mild conditions using water alone in the washing steps had been developed to efficiently remove hemicellulose and lignin and improve cellulose conversion efficiency [5]. Such pretreatment is potentially more cost-effective and energy efficient.

Building upon our previous work, the objectives of the present study were to estimate the hydrolysic potential of the crude cellulase complex using $\mathrm{HW}$ as the substrate by SSF as compared with a commercial cellulase blend and then to hydrolyze the organosolv-pretreated HW to reducing sugars which can be fermented to ethanol fuel (Fig. 1). To the best of our knowledge, this is the first attempt of generating bioethanol from this specific type of waste using such an integrated process.

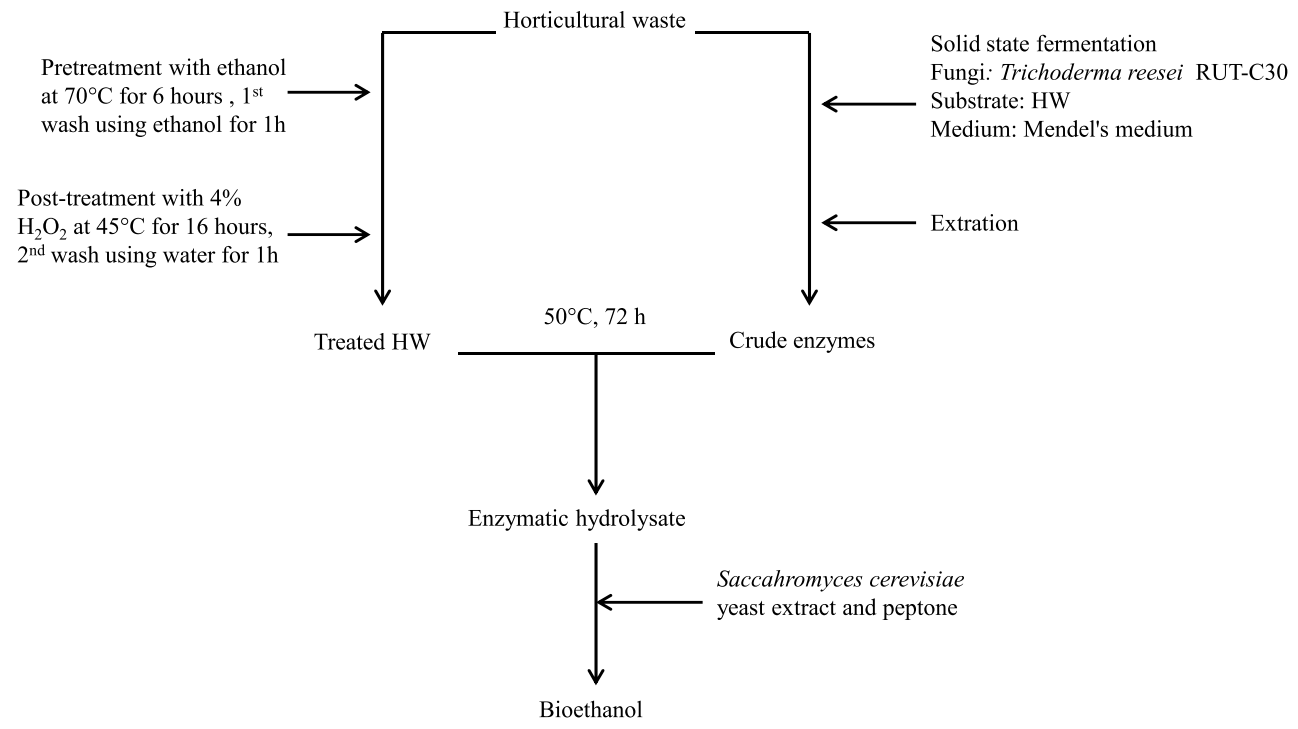

Fig. 1 Experiment layout for saccharification and fermentation of pretreated horticultural waste into fuel ethanol 


\section{Materials and Methods}

\section{Materials}

Horticultural waste including tree trunks and branches generated during the maintenance and pruning of trees and plants was sourced from a local company, Environmental Landscape Pte Ltd, Singapore. The collected HW was firstly washed using tap water to remove soil and dried at $60{ }^{\circ} \mathrm{C}$ overnight. Dried HW was mechanically ground with a lab mill (Ultra Centrifugal Mill ZM 200, Retsch $\mathrm{GmbH}$, Germany) and sieved through standard mesh sieves (200$500 \mu \mathrm{m})$ using an electronic sieve shaker model RP09 (Barcelona, Spain) to obtain powder of 200 to $500 \mu \mathrm{m}$ in particle size. All chemicals were of analytical grade and obtained from Sigma-Aldrich (St. Louis, MO, USA). Commercial $T$. reesei cellulase (Celluclast $1.5 \mathrm{~L}$ ) and a $\beta$-glucosidase preparation (Novozyme 188) were both kindly donated by Novozymes Malaysia sdn bhd.

\section{Microorganisms and Culture Conditions}

The cellulase hyper-producing fungus $T$. reesei RUT-C30 American Type Culture Collection (ATCC) 56765 and Saccharomyces cerevisiae ATCC 96581 were obtained from ATCC. T. reesei RUT-C30 was routinely maintained and sporulated on potato dextrose agar plate for 2 weeks until spore crop was developed. Four milliliters of sterile $0.05 \%$ Tween 80 solution was added to the plate and swirled to gently release the spores. Approximately $1 \mathrm{~mL}$ of the spore suspension consisting of $10^{6}-10^{7}$ spores was used as the inoculum. S. cerevisiae ATCC 96581 was maintained on YPD agar slants containing (g/L): glucose, 20.0; yeast extract, 10.0; peptone, 20.0; agar, 20.0 at $\mathrm{pH} 5.5 \pm 0.2$. It was incubated at $30^{\circ} \mathrm{C}$ for $24 \mathrm{~h}$, subsequently stored at $4{ }^{\circ} \mathrm{C}$, and subcultured on YPD plates at regular intervals. YPD medium containing $(\mathrm{g} / \mathrm{L})$ glucose-20.0, yeast extract-10.0, and peptone-10.0 was used as the seed culture medium. The HW enzymatic hydrolysate containing $25.06 \mathrm{~g} / \mathrm{L}$ of glucose and $1.64 \mathrm{~g} / \mathrm{L}$ xylose was supplemented to a final concentration of $(\mathrm{g} / \mathrm{L}) \mathrm{KH}_{2} \mathrm{PO}_{4}, 2.0 ; \mathrm{MgSO}_{4} \cdot 7 \mathrm{H}_{2} \mathrm{O}$, 1.0; yeast extracts, 10.0, and urea, 6.4. The $\mathrm{pH}$ was adjusted to $5.5 \pm 0.2$ unless otherwise mentioned using $2 \mathrm{M} \mathrm{NaOH}$. The synthetic medium containing the same amount of sugar $(25.06 \mathrm{~g} / \mathrm{L}$ of glucose and $1.64 \mathrm{~g} / \mathrm{L}$ xylose) with the same composition and initial $\mathrm{pH}$ was used as the control medium.

Enzyme Production and Enzymatic Assays

Solid-state fermentation was carried out as previously described [12]. Filter paper (FPase) and endo-glucanase (CMCase) activities were measured according to IUPAC recommendations [18]. FPase and CMCase activities were determined by measuring the reducing sugars produced from Whatman no. 1 filter paper (grade 3, catalog number 1003 150, Whatman International, UK) and $1 \%(w / v)$ carboxymethyl cellulose, respectively. Both reactions were carried out in $0.05 \mathrm{M}$ citrate buffer at $\mathrm{pH}$ 5.0. The reaction mixtures were incubated at $50{ }^{\circ} \mathrm{C}$ for $1 \mathrm{~h}$ and for $30 \mathrm{~min}$ for the FPase and CMCase activity assays, respectively. Xylanase activity was measured according to Ghose [19]. The assay was carried out in the total reaction mixture of $1.5 \mathrm{~mL}$ containing $0.5 \mathrm{~mL}$ of suitably diluted enzyme and $1.0 \mathrm{~mL}$ of $1 \%(w / v)$ xylan solution in phosphate buffer (0.05 M, pH 6.5). This mixture was incubated at $40{ }^{\circ} \mathrm{C}$ for $10 \mathrm{~min}$. The amount of reducing sugar released from FPase, CMCase, and xylanase activity assays was measured using the 3,5-dinitrosalicylic acid method [20]. $\beta$-Glucosidase and $\beta$-xylosidase activities were determined using the method described by Bailey et al. [21]. In this method, $p$-nitrophenol released from $1 \mathrm{mM} p$-nitrophenyl- $\beta$-d-glucopyranoside (Sigma N2132) and $p$-nitrophenyl- $\beta$-d-xylopyranoside (Sigma N-7006) was measured using a spectrophotometer (UV-1601 PC, Shimadzu, Japan). One unit (IU) of enzyme activity was defined as the amount of enzyme required to liberate $1 \mu \mathrm{mol}$ of product from their respective substrate per minute of crude filtrate under the assay conditions. The enzymatic hydrolysis was conducted in 50-mL Falcon tubes in $20 \mathrm{~mL}$ of $50 \mathrm{mM}$ sodium citrate buffer. The experiments were performed in duplicate in a shaking water bath (Memmert GmbH+Co. KG, Schwabach, Germany) with maximum strokes. Effects of temperature $\left(35-55{ }^{\circ} \mathrm{C}\right), \mathrm{pH}$ (4.5-7.0), enzyme loading (5-20 U/g HW), and solid content (5-25\%, based on biomass dry weight) were studied to obtain the final highest possible sugar concentration for ethanol fermentation. The glucose yields were calculated as: reducing sugar $(\mathrm{g}) \times 0.9 \times 100 /$ initial cellulose $(\mathrm{g})$ in biomass. Hydrolysis of polysaccharides involves water. For each mole of reducing sugar released, 1 mol of $\mathrm{H}_{2} \mathrm{O}$ is required. A correction factor of 0.9 was therefore included in the calculation of the amount of polysaccharides hydrolyzed. Experiments were carried out in duplicates.

\section{Chemical Characterization of Horticultural Waste}

The dried $\mathrm{HW}$ powder was soaked in $\mathrm{NaOH}$ solution at $105{ }^{\circ} \mathrm{C}$ for $12 \mathrm{~h}$. After the treatment, HW was washed using tap water to reach a neutral $\mathrm{pH}$ of 6.0-7.0, followed by a final rinse in distilled water. After this, they were dried in the oven at $90{ }^{\circ} \mathrm{C}$ for $1 \mathrm{~h}$. The final pretreated $\mathrm{HW}$ was cooled down at room temperature $\left(30 \pm 2{ }^{\circ} \mathrm{C}\right)$ and stored in polyethylene bags for further use. Mild-condition organosolv pretreatment was carried out according to our previous work [5]. The amount of hemicellulose, cellulose, and lignin in the lignocellulosic biomass was determined accord- 
ing to Yang et al. with modification [22]. To determine the amount of hemicellulose, $0.5 \mathrm{M} \mathrm{NaOH}$ solution was added to the dried biomass, and the temperature was held at $80^{\circ} \mathrm{C}$ for $3.5 \mathrm{~h}$. After that, the sample was washed until no more $\mathrm{Na}^{+}$was detected (indicated by the $\mathrm{pH}$ value of the solution approaching 7), and it was then dried to a constant weight. The difference between the sample weight before and after this treatment is the hemicellulose content. To determine the acid-soluble lignin content, $72 \% \mathrm{H}_{2} \mathrm{SO}_{4}$ was added to the hemicellulose-free biomass, followed by $2 \mathrm{~h}$ of incubation at $30{ }^{\circ} \mathrm{C}$. The mixture was then diluted to $4 \% \mathrm{H}_{2} \mathrm{SO}_{4}$ with de-ionized water. The diluted solution was autoclaved at $121{ }^{\circ} \mathrm{C}$ for $1 \mathrm{~h}$. The mixture was filtered. Aliquots of the filtrate were measured at the absorbance of $205 \mathrm{~nm}$ using $4 \% \mathrm{H}_{2} \mathrm{SO}_{4}$ as the control. Dilutions were done to obtain optical density readings of $0.2-0.8$. Acid-soluble lignin content was calculated based on the sample absorbance at $205 \mathrm{~nm}$. The rest of the biomass residue was washed until the sulfate ion in the filtrate was undetectable (via titration of a $10 \%$ barium chloride solution); it was then dried to a constant weight. The weight of the residue is recorded as the lignin content. Finally, the content of cellulose is calculated by the difference, assuming that hemicellulose, lignin, and cellulose are the only components of the entire biomass.

\section{Ethanol Fermentation}

One loop of $S$. cerevisiae was transferred from YPD plate after 1 day of growth to $150-\mathrm{mL}$ Erlenmeyer flask containing $50 \mathrm{~mL}$ of YPD medium. Yeasts were grown for $24 \mathrm{~h}$ at $150 \mathrm{rpm}$ on a rotary shaker at $30^{\circ} \mathrm{C}$. A total of $2 \mathrm{~mL}$ of such seed culture was inoculated to each $250-\mathrm{mL}$ Erlenmeyer flask (Sartorius, USA) containing $100 \mathrm{~mL}$ of the culture medium to make an initial biomass concentration of around $1.5 \mathrm{~g} / \mathrm{L}$. The HW enzymatic hydrolysate and the control medium were fermented by using $S$. cerevisiae in $250-\mathrm{mL}$ Erlenmeyer flasks sealed with screwed caps for $32 \mathrm{~h}$. The shaking speed was kept at $150 \mathrm{rpm}$ and temperature at $30^{\circ} \mathrm{C}$. Samples were withdrawn periodically to determine the concentration of sugar, ethanol, and cell biomass in the fermentation broth. Fermentation experiments were conducted in duplicate.

\section{Analytical Methods}

Cell biomass was monitored spectrophotometrically by measuring absorbance at $600 \mathrm{~nm}$ using a spectrophotometer (UV-1601 PC, Shimadzu, Japan). Measurement was made such that the optical density $\left(\mathrm{OD}_{600}\right)$ of the samples was smaller than 0.70 , as obtained by sample dilution. This is to ensure that Beer-Lambert law applies. Forty-milliliter samples of whole culture were filtered through $0.45-\mu \mathrm{m}$ pre-dried, pre-weighed glass fiber membrane filters and dried at $60{ }^{\circ} \mathrm{C}$ until a constant weight was obtained. Biomass dry weight was calculated as the difference between the membrane dry weight before and after the culture broth filtration. A calibration curve was prepared between $\mathrm{OD}_{600}$ and biomass dry weight. The OD value was then converted to biomass dry weight using such calibration curve. Biomass concentration (grams per liter) was found to follow the regression equation: $\mathrm{X}(\mathrm{g} / \mathrm{L})=0.314 \times\left(\mathrm{OD}_{600}\right)$. Samples were filtered through $0.45-\mu \mathrm{m}$ filters and stored at $20{ }^{\circ} \mathrm{C}$ until analyzed by a 1200 Series HPLC system (Agilent Tech- nologies Inc.) equipped with a refractive index detector. Glucose and ethanol were analyzed on an Aminex HPX-87H column (Bio-Rad, Richmond, CA, USA) at $75{ }^{\circ} \mathrm{C}$ with $0.6 \mathrm{~mL} / \mathrm{min}$ eluent of $5 \mathrm{mM}$ sulfuric acid.

\section{Results and Discussion}

Hydrolytic Potential of the Crude Enzyme Complex Produced Under SSF

T. reesei RUT-C30 is one of the most powerful and best characterized cellulolytic strains and is considered as a model cellulase producer [10-12]. Numerous industrial and agricultural residues have been evaluated for cellulase production using SSF by $T$. reesei [10-12, 23-25]. HW, one of the most produced lignocellulosic wastes in Singapore, was chosen as the substrate for cellulase production under SSF by $T$. reesei RUT-C30 in our lab [12]. In our previous work, crude enzyme mixture containing FPase (15.0 U/g SDM), CMCase (90.5 U/g SDM), $\beta$-glucosidase (61.6 U/g SDM), xylanase $(52.1 \mathrm{U} / \mathrm{g} \mathrm{SDM})$, and $\beta$-xylosidase $(10.4 \mathrm{U} / \mathrm{g}$ SDM) was obtained at $30{ }^{\circ} \mathrm{C}$, initial $\mathrm{pH}$ value of 5.0 , and $80 \%$ moisture content using the steam-pretreated HW of $200-500 \mu \mathrm{m}$ in particle size [12]. In order to investigate the hydrolytic potential of the crude enzyme complex produced by $T$. reesei RUT-C30 under SSF using HW, a comparison of the effectiveness of crude enzyme samples and a commercial enzyme preparation for the saccharification of Whatman filter paper was made (Fig. 2). Yield of enzymatic hydrolysis using the laboratory-produced crude enzyme solution was slightly higher (72.2\%) than the commercial enzyme mixture $(68.7 \%)$ when using the same unit of cellulase activity ( $15 \mathrm{PFU} / \mathrm{g}$ filter paper). The increased yield of hydrolysis using the crude enzyme could be due to the fact that the crude enzyme solution prepared possessed slightly higher hemicellulases activities than the commercial enzymes, which could contribute to the slightly higher reducing sugar concentration. The said results imply that the crude enzymes produced under SSF using HW as the substrate have a comparable hydrolytic potential with com- 


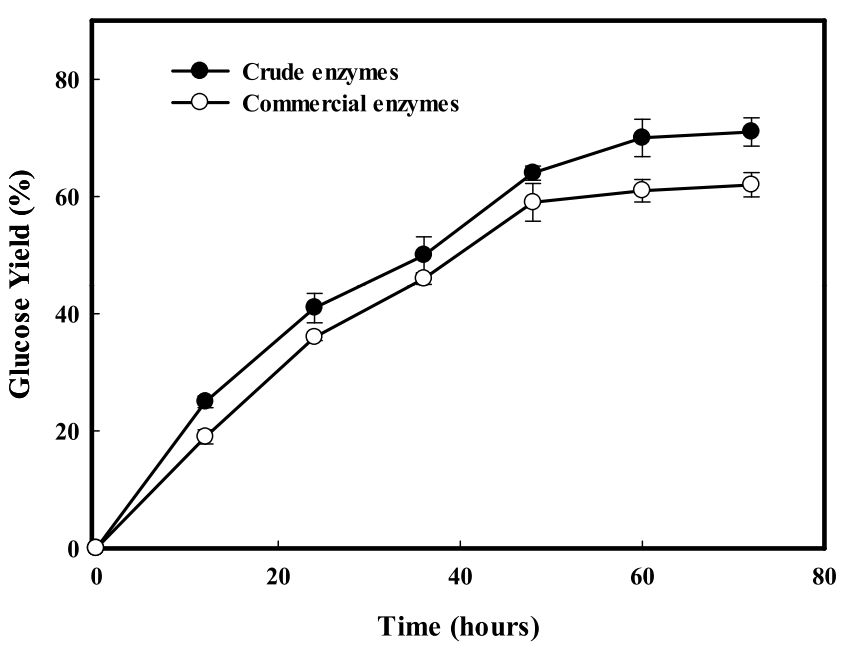

Fig. 2 Comparison of the hydrolysis potentials of Whatman filter paper using the crude enzyme sample and the commercial enzyme mixture

mercial enzymes, which can be used for subsequent enzymatic hydrolysis.

Organosolv Pretreatment Increase the Accessibility of Cellulose

The composition of the pretreated biomass is a good indication of the biomass pretreatment efficiency. Some effective pretreatments enrich cellulose at the expense of hemicellulose and lignin contents [26]. Dilute acid pretreatment is the most studied process for agriculture biomass and can be effective for woody biomass [26-28]. When poplar wood was pretreated at $190{ }^{\circ} \mathrm{C}$ and $2 \%$ acid charge, total sugar recovery of $82.8 \%$ with a cellulase loading of $15 \mathrm{FPU} / \mathrm{g}$ cellulose was yielded [28]. Recently Wang et al. [29] reported a cellulose conversion of over $80 \%$ from a eucalyptus substrate. The substrate was derived from direct dilute acid pretreatment of wood chips $(6-38 \mathrm{~mm})$ at $180{ }^{\circ} \mathrm{C}$ with a sulfuric acid charge of $1.84 \%$ on wood followed by a disk-milling process for size reduction. The cellulase loading was $15 \mathrm{FPU} / \mathrm{g}$ substrate. Although dilute acid pretreatment could provide satisfactory enzymatic cellulose conversion for some woody biomass, it was achieved at the expense of increased thermal energy cost. Dilute $\mathrm{NaOH}$ pretreatment had been proven to be effective for the hydrolysis of straws with relatively low lignin content of $10-18 \%$ [14]. However, no obvious effect of dilute $\mathrm{NaOH}$ pretreatment was observed for softwoods with lignin content greater than $26 \%$ [30]. When $\mathrm{HW}$ was treated with $1 \%$ dilute $\mathrm{NaOH}$ at $105^{\circ} \mathrm{C}$ for $1 \mathrm{~h}$, the sugar yield increased to $38.3 \%$. Recently, a cold sodium hydroxide pretreatment achieved about $70 \%$ enzymatic glucose yield from spruce when the pretreatment was conducted at $-15^{\circ} \mathrm{C}$ in a $7 \%(w / v) \mathrm{NaOH}$ solution with $12 \%(w / v)$ urea [31]. The problem of this process is its expense and the difficulty in recovering $\mathrm{NaOH}$. An alternate pretreatment is a modified organosolv pretreatment that efficiently removed lignin and hemicellulose under noncorrosive and mild conditions using water alone in the washing steps and resulted in a high sugar yield (50.9\%) and enriched cellulose content (51.1\%) [5]. As for hemicellulose, the contents were 37.2 and $21.2 \%$ respectively when using $\mathrm{NaOH}$ and organosolv. Removal of hemicellulose increases the mean pore size of the substrate and therefore increases access of cellulases to the cellulose fibers [13, 14]. In addition, both $\mathrm{NaOH}$ and organosolv pretreatments resulted in decreased lignin content compared with the untreated HW, indicating the removal of lignin in the pretreatment process. However, under the conditions used in this study, hemicellulose but not lignin was removed. This can be attributed to the mild conditions adopted and the elimination of the acid catalyst in the pretreatment process. These results confirmed that ethanosolv pretreatment is an efficient method for cellulose retention. Based on the cited analysis, organosolv is a more efficient pretreatment method, especially for woody biomass, and the organosolvpretreated HW will be used in the next experiments.

\section{Effect of Temperature and $\mathrm{pH}$ on Enzymatic Hydrolysis}

Almost all reported studies on enzymatic hydrolysis of cellulose or lignocelluloses using commercial $T$. reesei cellulase were conducted at $\mathrm{pH} 4.8$ and at 5.0 with temperatures near $50{ }^{\circ} \mathrm{C}$. These conditions were selected based on laboratory studies of enzyme activities using controlled substrates, i.e., pure cellulose (Product Sheet Celluclast 1.5 L, Novozymes). Lan et al. recently found that the optimal $\mathrm{pH}$ ranges for achieving high and stable enzymatic saccharification efficiency of lignocellulosic substrates are different from those for pure cellulosic substrates [32]. The optimal measured $\mathrm{pH}$ of the suspension at hydrolysis temperature $50{ }^{\circ} \mathrm{C}$ was at 6.0 or higher for the lignocellulosic substrates, while the optimal $\mathrm{pH}$ for the Whatman paper is around 4.5 [32]. In order to test the optimal temperature and $\mathrm{pH}$ using organosolv-treated HW for enzymatic saccharification, different temperature $\left(35-55{ }^{\circ} \mathrm{C}\right)$ and $\mathrm{pH}$ ranges (4.5-7.0) were carried out. At 45,50 , and $55^{\circ} \mathrm{C}$, the reducing sugar yields were $32.5,51.3$, and $45.6 \%$, respectively. Maximum rate of hydrolysis was achieved at $50^{\circ} \mathrm{C}$, which is similar to the reports using commercial T. reesei cellulase (Fig. 3). The decrease of the enzyme activity at higher temperature $\left(55^{\circ} \mathrm{C}\right)$ may be due to the partial denaturation of the enzymes. The effect of $\mathrm{pH}$ on sugar yield of the crude cellulase complex was checked over a range from $\mathrm{pH} 4.5$ to 7.0 (Fig. 4). High and stable sugar yield was obtained in an acidic environment in the range of $\mathrm{pH}$ 5.0-6.0, with the highest sugar yield (48.5\%) observed at $\mathrm{pH} 5.5$, which is higher than the pure cellulosic substrates (Whatman paper, 


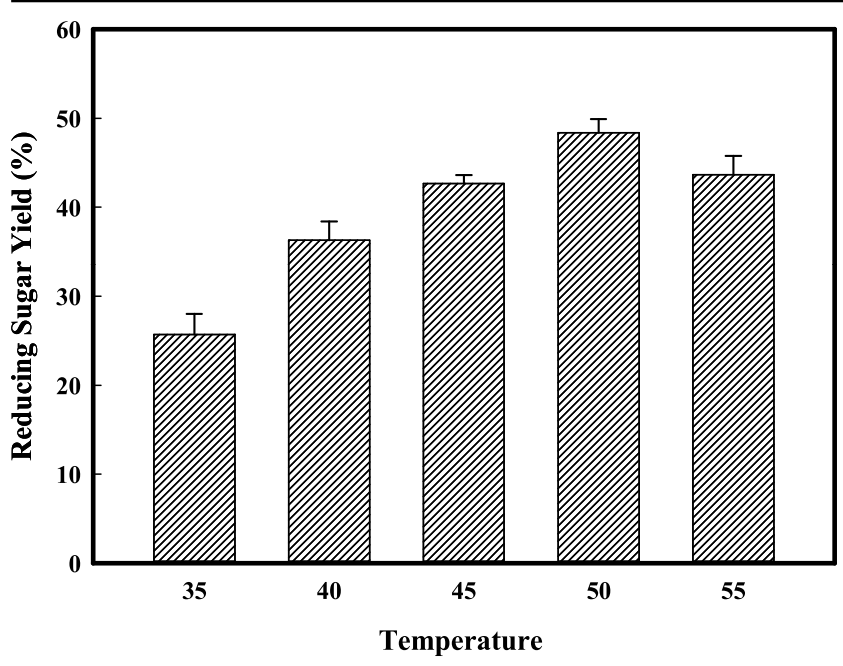

Fig. 3 Effect of temperature on the reducing sugar yield (\%) in the HW hydrolysate obtained after hydrolysis at pH5.0, $10 \mathrm{FPU} / \mathrm{g} \mathrm{HW}$ at $72 \mathrm{~h}$

BKP-LbP) and similar to the reported lignocellulosic substrates [32]. The differences from the pure cellulosic substrate and similarity to the reported lignocellulosic substrates are due to the variations in $\mathrm{pH}$-induced surface charge of different substrates with different surface functional groups. This surface charge variation can produce different effects on hydrophobic /hydrophilic and perhaps electrostatic interactions between cellulase and lignin in reducing cellulase nonproductive binding to lignin, therefore enhancing saccharification among different substrates. Therefore, $50{ }^{\circ} \mathrm{C}$ and $\mathrm{pH} 5.5$ were adopted for the following experiments [32].

\section{Effect of Enzyme Load on Enzymatic Hydrolysis}

A reasonable cellulase dosage depends on the reaction time (generally, 48-72 h) and enzyme cost. Cellulase enzyme

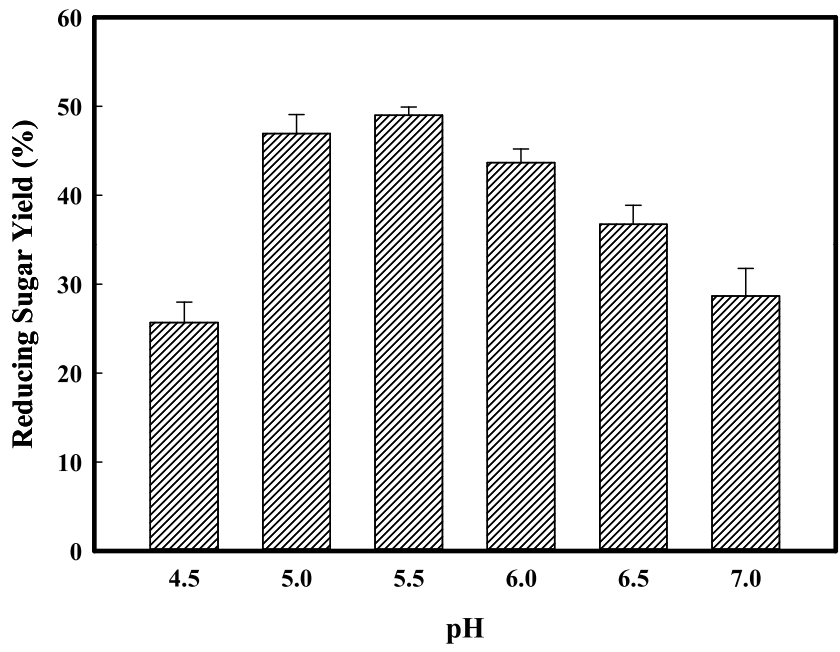

Fig. 4 Effect of $\mathrm{pH}$ on the reducing sugar yield (\%) in the HW hydrolysate obtained after hydrolysis at $50{ }^{\circ} \mathrm{C}, 10 \mathrm{FPU} / \mathrm{g} \mathrm{HW}$ at $72 \mathrm{~h}$ loadings in hydrolysis vary from 7 to $33 \mathrm{FPU} / \mathrm{g}$ substrate, depending on the types and concentrations of substrates [14]. To investigate the effect of cellulase loading on the sugar yield of pretreated HW, different cellulase loading dosages (5-20 FPU/g pretreated HW) were used. As shown in Fig. 5, sugar yield increased with increasing cellulase loading from 3 to $15 \mathrm{FPU} / \mathrm{g}$ pretreated HW. A $54.9 \%$ sugar yield was obtained when cellulase loading was $15 \mathrm{FPU} / \mathrm{g}$ pretreated HW. An increase of $65.6 \%$ of sugar yield was obtained at this condition compared with that obtained with $5 \mathrm{FPU} / \mathrm{g}$ pretreated HW. However, further increase of the cellulase dosage did not contribute to further increase in hydrolysis yield. This might be due to the inhibitory effects which resulted from the accumulation of end-products such as glucose and cellobiose obtained at higher cellulase concentration or due to the insufficient contact of the enzymes and the substrate under such condition. As such, cellulase loading of $15 \mathrm{FPU} / \mathrm{g}$ pretreated HW was considered as the optimum value and it was adopted throughout the rest of the experiments.

\section{Effect of Substrate Load on Enzymatic Hydrolysis}

During industrial operations, higher biomass loadings of $15 \%(w / v)$ or higher can result in higher sugar concentrations and greater ethanol titers [5]. Therefore, experiments were conducted to determine the impact of varying the solid content $(w / v)$ from 5 to $25 \%$ reducing sugar concentration. The final sugar concentrations with varying solid contents after enzymatic hydrolysis of organosolv-treated HW are given in Fig. 6. The cellulase dosage was $15 \mathrm{FPU} / \mathrm{g} \mathrm{HW}$. Experiments were conducted at $50{ }^{\circ} \mathrm{C}, \mathrm{pH} 5.5$ for $72 \mathrm{~h}$. Reducing sugar concentration increased with the increase of

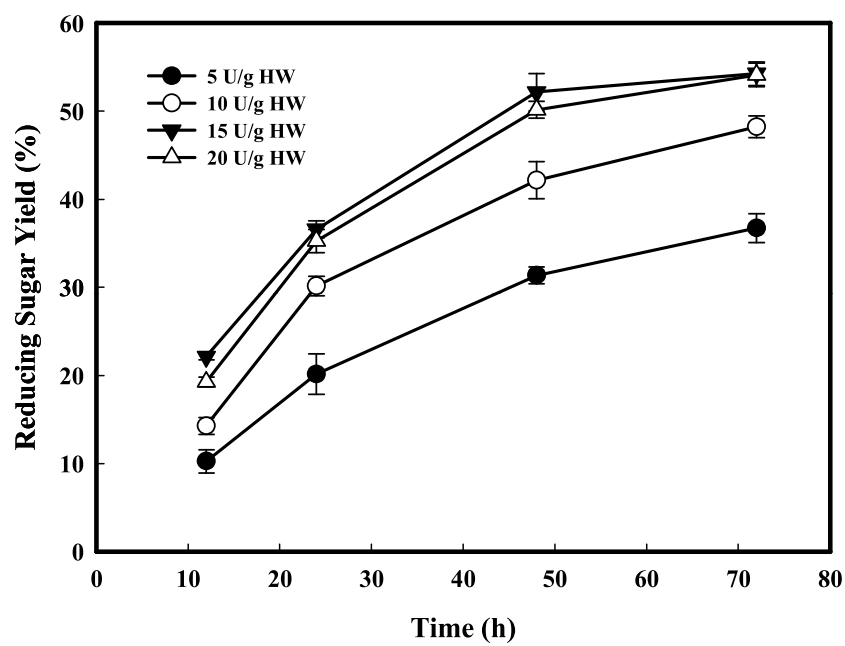

Fig. 5 Effect of the enzyme loading on the reducing sugar yield (\%) in the HW hydrolysate obtained after hydrolysis at $50{ }^{\circ} \mathrm{C}, \mathrm{pH} 5.5$ at $72 \mathrm{~h}$ 


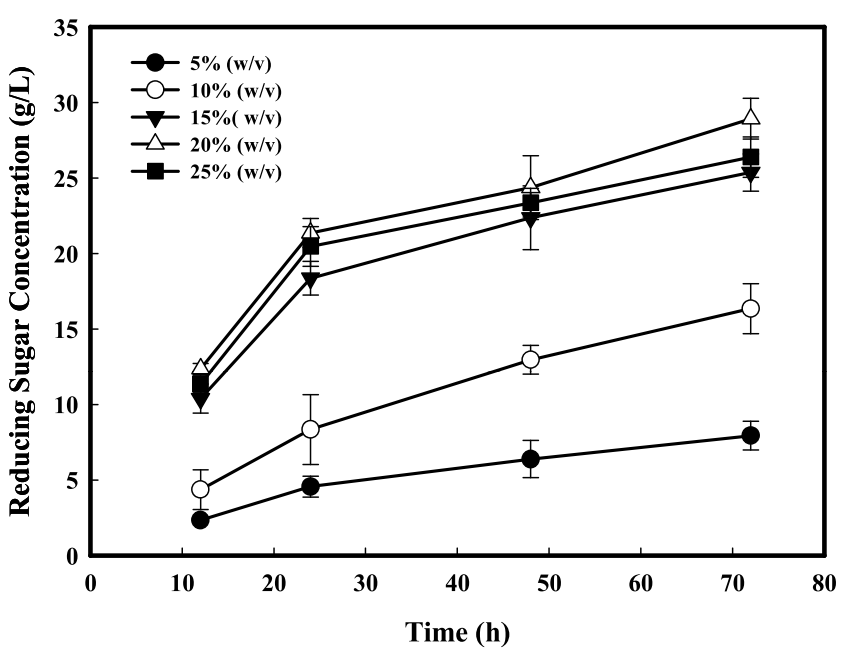

Fig. 6 Effect of the solid content $(w / v)$ on the reducing sugar concentration $(\mathrm{g} / \mathrm{L})$ in the HW hydrolysate obtained after hydrolysis at $50{ }^{\circ} \mathrm{C}, \mathrm{pH} 5.5,15 \mathrm{FPU} / \mathrm{g} \mathrm{HW}$ at $72 \mathrm{~h}$

HW loading, and it reached a plateau when the solid content was $20 \%(w / v)$. The maximum sugar concentration obtained was $25.06 \mathrm{~g} / \mathrm{L}$. Further increase in the solid content did not result in any increase in sugar concentration. This might be because of mass transfer effects or end-product inhibition.

\section{Fermentation by S. cerevisiae}

Generally, side products formed during pretreatment act as microbial inhibitors; these include furans, weak organic acids, and aromatics $[13,16]$. In order to compare whether the enzymatic hydrolysate of HW has a negative effect on the fermentation performance of $S$. cereviase, the fermentation results were compared with the control media containing the same concentration glucose, $25.06 \mathrm{~g} / \mathrm{L}$, and xylose,

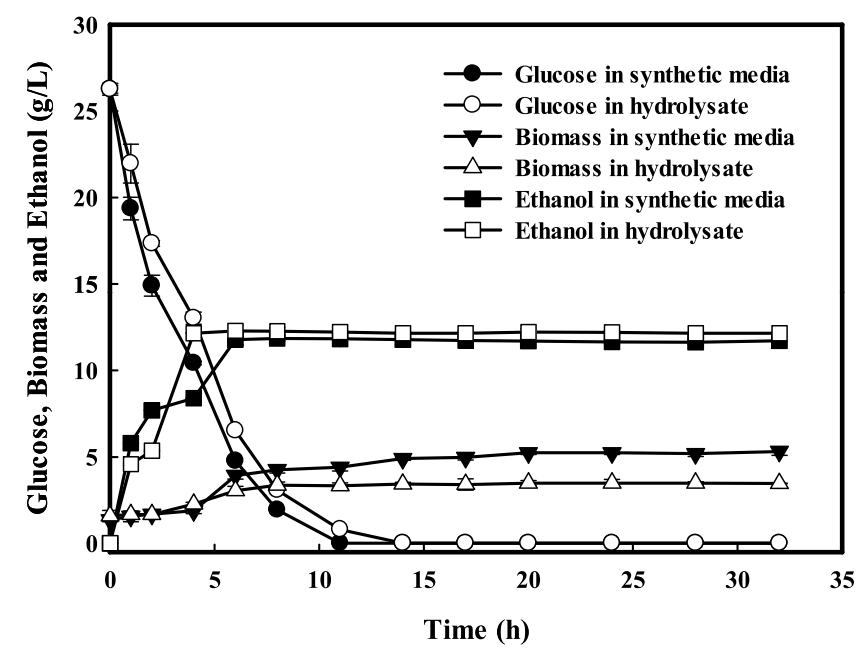

Fig. 7 Fermentation profile of enzymatic hydrolysate of HW and the control medium by $S$. cerevisiae
$1.64 \mathrm{~g} / \mathrm{L}$, without any inhibitor. Figure 7 shows the time course of fermentation profile using the hydrolysate and the synthetic medium. Fermentation was performed at $30{ }^{\circ} \mathrm{C}$ (pH 5.5), $150 \mathrm{rpm}$ for $32 \mathrm{~h}$. All of the glucose was consumed in the two media. S. cerevisiae is unable to ferment xylose; however, a slight decrease was noted for both cases (data not shown). This was consistent with prior results [5]. The maximum cell and ethanol concentration was found to be 3.37 and $12.39 \mathrm{~g} / \mathrm{L}$, respectively, after $8 \mathrm{~h}$ of fermentation in the hydrolysate (Table 1). Ethanol yield $\left(Y_{\mathrm{p} / \mathrm{s}}\right)$ and productivity $\left(Q_{\mathrm{p}}\right)$ was estimated to be $0.49 \mathrm{~g}$ per gram of glucose $(91.98 \%$ of theoretical yield) and $0.062 \mathrm{~g}$ per gram of HW and $1.55 \mathrm{~g} / \mathrm{L} / \mathrm{h}$, respectively. Similarly in synthetic media (supplemented with synthetic sugar glucose), ethanol yield and productivity were $0.47 \mathrm{~g} / \mathrm{g}$ and $1.48 \mathrm{~g} / \mathrm{L} / \mathrm{h}$, respectively, with specific ethanol productivity of $0.35 \mathrm{~g} / \mathrm{L} / \mathrm{h} / \mathrm{g}$ biomass (Table 1). The similar ethanol yield and productivity obtained from HW hydrolysate and the control medium (Table 1) indicate that HW hydrolysate is quite fermentable and no prior detoxification is required. The highest yield obtained by Gupta et al. [33] was given as $0.49 \mathrm{~g} / \mathrm{g}$ by using commercial enzyme for hydrolysis and fermentation by $S$. cerevisiae, which is similar to the present study. In addition, HW hydrolysate seemed to have a slightly positive effect in ethanol production as evidenced by the higher specific ethanol productivity. This is probably owing to the presence of the hydrolysis by-product, such as acetic acid, which is known to enhance the fermentation rate at a low concentration $[30,33]$. The fermentation results presented here show that the organosolv-pretreated HW using the crude cellulase enzymes produced from HW under SSF is a promising process for bioconversion of HW to value-added products, such as fuels and chemicals.

Table 1 Fermentation parameters for bioethanol production in enzymatically hydrolyzed (crude enzyme) sugars and synthetic sugars media by $S$. cerevisiae

\begin{tabular}{|c|c|c|}
\hline Kinetic parameters & Hydrolysate media & Synthetic media \\
\hline Initial glucose, $S 0(\mathrm{~g} / \mathrm{L})$ & $25.06+0.32$ & $25.06+0.56$ \\
\hline $\begin{array}{l}\text { Maximum ethanol } \\
\text { concentration }(\mathrm{g} / \mathrm{L})\end{array}$ & $12.39+0.12$ & $11.85+0.32$ \\
\hline $\begin{array}{l}\text { Maximum cell } \\
\text { concentration }(\mathrm{g} / \mathrm{L})\end{array}$ & $3.37+0.05$ & $4.25+0.18$ \\
\hline Maximum time (h) & 8 & 8 \\
\hline Glucose consumed (\%) & 100 & 100 \\
\hline $\begin{array}{l}\text { Ethanol yield } \\
\quad \text { coefficient, } Y_{\mathrm{p} / \mathrm{s}}(\mathrm{g} / \mathrm{g})\end{array}$ & $0.49+0.002$ & $0.47+0.006$ \\
\hline $\begin{array}{l}\text { Biomass yield } \\
\quad \text { coefficient, } Y_{\mathrm{x} / \mathrm{s}}(\mathrm{g} / \mathrm{g})\end{array}$ & $0.13+0.06$ & $0.17+0.07$ \\
\hline $\begin{array}{l}\text { Ethanol productivity, } \\
\qquad Q \mathrm{p}(\mathrm{g} / \mathrm{L} / \mathrm{h})\end{array}$ & $1.55+0.05$ & $1.48+0.12$ \\
\hline $\begin{array}{l}\text { Specific ethanol productivity } \\
\text { (g/L/h/g biomass) }\end{array}$ & $0.46+0.06$ & $0.35+0.21$ \\
\hline $\begin{array}{l}\text { Maximum sugar consumption } \\
\quad \text { rate, } Q_{\mathrm{s}}(\mathrm{g} / \mathrm{L} / \mathrm{h})\end{array}$ & $3.13+0.12$ & $3.13+0.09$ \\
\hline
\end{tabular}




\section{Conclusions}

According to recent techno-economic evaluations, the main contributors to the overall costs of producing ethanol from biomass are the raw material (30-40\%) and the capital investment (30-45\%), followed by the cellulase enzymes $(10-20 \%)[1,2]$. In Singapore, horticultural waste is the most commonly generated lignobiomass waste, which is a potential feedstock for both fuel ethanol and cellulase production. In the present study, organosolv-treated HW was firstly saccharified using crude enzymes produced from untreated $\mathrm{HW}$ under solid-state fermentation instead of commercial enzymes and then fermented to fuel ethanol. A total of $6.2 \mathrm{~g}$ of ethanol could be produced from $0.1 \mathrm{~kg}$ of $\mathrm{HW}$ without any usage of commercial cellulase. Implementing this process will add value to what is now treated as a waste product.

Open Access This article is distributed under the terms of the Creative Commons Attribution Noncommercial License which permits any noncommercial use, distribution, and reproduction in any medium, provided the original author(s) and the source are credited.

\section{References}

1. Field CB, Campbell JE, Lobell DB (2008) Biomass energy: the scale of the potential resource. Trends Ecol Evol 23:65-72

2. Galbe M, Zacchi G (2007) Pretreatment of lignocellulosic materials for efficient bioethanol production. Adv Biochem Eng/ Biotechnol 108:41-65

3. Nguyen QA, Saddler JN (1991) An integrated model for the technical and economic evaluation of an enzymatic biomass conversion process. Bioresour Technol 35:275-282

4. Sun Y, Cheng JY (2002) Hydrolysis of lignocellulosic materials for ethanol production: a review. Bioresour Technol 83:1-11

5. Geng AL, Xin FX, Ip JY (2012) Ethanol production from horticultural waste treated by a modified organosolv method. Bioresour Technol 104:715-721

6. Zhu JY, Pan XJ (2010) Woody biomass pretreatment for cellulosic ethanol production: technology and energy consumption evaluation. Bioresour Technol 101:4992-5000

7. Chahal DS (1985) Solid state fermentation with Trichoderma reesei for cellulase production. Appl Environ Microbiol 49:205-210

8. Singhania RR, Patel AK, Soccol CR, Pandey A (2009) Recent advances in solid state fermentation. Biochem Eng J 44:13-18

9. Kim J, Hosobuchi M, Kishimoto M, Seki T, Yoshida T, Taguchi H (1985) Cellulase production by a solid state culture system. Biotechnol Bioeng 27:1445-1450

10. Maheswari D, Jahan H, Paul J, Varma A (1993) Wheat straw, a potential substrate for cellulase production using Trichoderma reesei. World J Microbiol Biotechnol 9:120-121

11. Singhania R, Sukumaran R, Pillai A, Prema P, Szakacs G, Pandey A (2006) Solid state fermentation on lignocellulosic substrates for cellulase production by Trichoderma reesei NRRL 11460 . Indian J Biotechnol 5:332-336

12. Xin FX, Geng AL (2010) Horticultural waste as the substrate for cellulase and hemicellulase production by Trichoderma reesei under solid state fermentation. Appl Biochem Biotechnol 162:295-306

13. Mosier N, Wyman CE, Dale BE, Elander RT, Lee YY, Holtzapple M, Ladisch MR (2005) Features of promising technologies for pretreatment of lignocellulosic biomass. Bioresour Technol 96:673-686

14. Wyman CE, Dale BE, Elander RT, Holtzapple M, Ladisch MR, Lee YY (2005) Coordinated development of leading biomass pretreatment technologies. Bioresour Technol 96:1959-1966

15. Pan XJ, Xie D, Kan KY, Yoon SL, Saddler JN (2007) Effect of organosolv ethanol pretreatment variables on physical characteristics of hybrid poplar substrates. Appl Biochem Biotechnol 137:367-377

16. Araque E, Parra C, Freer J, Contreras D, Rodriguez J, Mendonca R, Baeza J (2008) Evaluation of organosolv pretreatment for the conversion of Pinus radiata D. Don to ethanol. Enzyme Microb Technol 3:214-219

17. Sannigrahi P, Miller SJ, Ragauskas AJ (2010) Effects of organosolv pretreatment and enzymatic hydrolysis on cellulose structure and crystallinity in Loblolly pine. Carbohydr Res 345:965-997

18. Ghose TK (1987) Measurement of cellulase activity. Pure Appl Chem 59:257-268

19. Ghose TK, Bisaria VS (1987) Measurement of hemicellulase activity. Pure Appl Chem 59:1739-1752

20. Miller GL (1959) Use of dinitrosalicylic acid reagent for determination of reducing sugars. Anal Chem 31:426-428

21. Bailey MJ, Biely P, Poutanen K (1992) Interlaboratory testing of methods for assay of xylanase activity. J Biotechnol 23:257-270

22. Yang HP, Yan R, Chen HP, Zheng CG, Lee DH, Liang DT (2006) An in-depth investigation of biomass pyrolysis based on three major components: xylan, cellulose and lignin. Energy Fuel 20:388-393

23. Chahal P, Chahal D, Le B (1996) Production of cellulase in solidstate fermentation with Trichoderma reesei MCG 80 on wheat straw. Appl Biochem Biotechnol 57:433-442

24. Deschamps F, Giuliano C, Asther M, Huet M, Roussos S (1982) Cellulase production by Trichoderma harzanium in static and mixed solid-state fermentation reactors under nonaseptic conditions. Biotechnol Bioeng 27:1385-1388

25. Mekala NK, Singhania RR, Sukumaran RK, Pandey A (2008) Cellulase production under solid-state fermentation by Trichoderma reesei RUT C30: statistical optimization of process parameters. Appl Biochem Biotechnol 151:122-131

26. Teramoto Y, Lee SH, Endo T (2008) Pretreatment of woody and herbaceous biomass for enzymatic saccharification using sulphuric acid-free ethanol cooking. Bioresour Technol 99:8856-8863

27. Millet MA, Baker AJ, Scatter LD (1976) Physical and chemical pretreatment for enhancing cellulose saccharification. Biotechnol Bioeng Symp 6:125-153

28. Wyman CE, Dale BE, Elander RT, Holtzapple M, Ladisch MR, Lee YY, Mitchinson C, Saddler JN (2009) Comparative sugar recovery and fermentation data using following pretreatment of poplar wood by leading technologies. Biotechnol Prog 25:333-339

29. Wang GS, Pan XJ, Zhua JY, Gleisner R (2009) Sulfite pretreatment to over recalcitrance of lignocelluloses (SPORL) for robust enzymatic saccharification of hardwoods. Biotechnol Prog 25:1086-1093

30. Cheung SW, Anderson BC (1997) Laboratory investigation of ethanol production from municipal primary wastewater solids. Bioresour Technol 59:81-96

31. Zhao Y, Wang Y, Zhu JY, Ragauskas AJ, Deng YL (2008) Enhanced enzymatic hydrolysis of spruce by alkaline pretreatment at low temperature. Biotechnol Bioeng 99:1320-1328

32. Lan TQ, Lou HM, Zhu JY (2012) Enzymatic saccharification of lignocelluloses should be conducted at elevated $\mathrm{pH}$ 5.2-6.2. Bioenerg Res 24 Oct. doi:10.1007/s12155-012-9273-4

33. Gupta R, Sharma KK, Kuhad RC (2009) Separate hydrolysis and fermentation (SHF) of Prosopis juliflora, a woody substrate, for the production of cellulosic ethanol by Saccharomyces cerevisiae and Pichia stipitis-NCIM 3498. Bioresour Technol 100:1214-1220 